\title{
Analisis Penerimaan Sistem Informasi Pada Rumah Sakit Umum Daerah Sidoarjo
}

\author{
Ainul Fithrotul A'yun', Wildan Suharso ${ }^{2 *}$, Evi Dwi Wahyuni3 \\ 1,2,3) Universitas Muhammadiyah Malang \\ Jl. Raya Tlogomas No. 246 Malang \\ ainulfayun@gmail.com,wsuharso@umm.ac.id
}

\begin{abstract}
Information systems become an important part in all areas of life, one of which is a hospital that uses information systems as a support for business processes. The level of user acceptance of the information system in the hospital needs to be reviewed and analyzed as a way to improve service because the main factors that play an important role are users. This study analyzes the factors that influence the acceptance of users of information using the TAM (Technology Acceptance Model). This study uses employee data as a sample, 30 respondents used to test the validity and reliability, from the number of 1436 employees used 112 respondents and the questionnaire returned was 94 questionnaires. Determination of the number of respondents based on Slovin formula shows the number used is 94 respondents. The research methodology includes literature study, determination of research variables, data collection and observation, hypothesis determination, instrument development, questionnaire distribution, data processing and analysis of results. In the development of instruments found 6 variables with 32 indicators, and 35 question items. Based on the validity test found 5 indicators that are not used and Cronbach's alpha value of 0.912 which means that the value is greater than 0.6 so that the instrument is reliable. Research shows that the correlation of the final results shows that the significance level is below 0.05 and shows that the independent variables have a significant influence on the dependent variable, so it can be concluded that user acceptance of the technology in Sidoarjo Regional General Hospital is good.
\end{abstract}

Keywords: SIMRS, Hospital, Information System, TAM, Correlation

\begin{abstract}
Abstrak
Sistem informasi menjadi bagian penting, salah satunya Rumah Sakit yang menggunakan sistem informasi sebagai penyokong proses bisnis. Tingkat penerimaan pengguna terhadap sistem informasi yang ada di Rumah Sakit perlu ditelaah dan dianalisis sebagai salah satu cara meningkatkan pelayanan karena faktor utama yang memegang peranan penting adalah pengguna. Penelitian ini menganalisis faktor-faktor yang mempengaruhi penerimaan pengguna informasi menggunakan TAM (Technology Acceptance Model). Penelitian ini menggunakan data karyawan sebagai sampel, 30 responden digunakan untuk uji validitas dan reliabilitas, dari jumlah 1436 karyawan digunakan 112 responden dan kuesioner yang kembali berjumlah 94 kuesioner. Penentuan jumlah responden berdasarkan rumus slovin menunjukkan jumlah yang digunakan adalah 94 responden. Metodologi penelitian meliputi studi literatur, penentuan variabel penelitian, pengumpulan data dan observasi, penentuan hipotesis, pengembangan instrumen, penyebaran kuesioner, pengolahan data dan analisis hasil. Pada pengembangan instrumen ditemukan 6 variabel dengan 32 indikator, dan 35 item pertanyaan. Berdasarkan uji validitas ditemukan 5 indikator yang tidak digunakan dan nilai Cronbach's alpha sebesar 0,912 yang mengartikan bahwa nilai lebih besar dari 0,6 sehingga instrumen dikatan reliabel. Penelitian menunjukkan bahwa korelasi Hasil akhir penelitian menunjukkan bahwa tingkat signifikansi dibawah 0,05 dan menunjukkan bahwa variabel independen mempunyai pengaruh signifikan terhadap variabel dependen, sehingga dapat disimpulkan penerimaan pengguna terhadap teknologi di RSUD Sidoarjo adalah baik.
\end{abstract}

Kata kunci: SIMRS, Rumah Sakit, Sistem Informasi, TAM, Korelasi

Analisis Sistem Informasi Pada Rumah Sakit Umum (Ainul Fithrotul A'yun)|210 


\section{PENDAHULUAN}

Teknologi komunikasi dan informasi terus berkembang dan mempengaruhi kegiatan di seluruh bidang kehidupan. Perkembangan teknologi memaksa manusia untuk beradaptasi dari industri produksi masal kepada industri yang terotomasi yang memanfaatkan teknologi komputer. Adaptasi juga dilakukan oleh pelaku bisnis pada bidang yang lain yang menjadikan teknologi informasi, internet dan komputer sebagai bagian utama dari kegiatan pada bidang pendidikan [1]. Informasi yang berkualitas dapat diperoleh dari dukungan sistem informasi yang berkualitas [2]. Sistem informasi manajemen merupakan suatu sistem yang dapat membantu perusahaan dalam hal manajemen, aktifitas dan operasi yang saling terkait dalam sistem [3]. Sistem informasi manajemen (SIM) seharusnya dapat mengakomodasi kebutuhan bisnis, manajemen perusahaan sehingga dapat digunakan sebagai bahan untuk pengambilan keputusan.

Sistem informasi saat ini telah digunakan untuk menyelesaikan banyak permasalahan, antara lain untuk menyelesaikan permasalahan manajemen perangkat lunak [4], untuk menyelesaikan permasalahan laporan yang rutin dilakukan di bidang pendidikan [5], permasalahan pengembalian buku pada perpustakaan [6], rancang bangun website pada instansi pemerintah [7]. Namun analisis perlu dilakukan untuk mengetahui sejauh mana tingkat penggunaan sistem informasi [8], analisis sistem informasi juga perlu dilakukan untuk mengetahui sejauh mana tingkat kemudahan dan kemanfaatan terhadap penerimaan pengguna [9]. Sistem informasi juga perlu diterapkan pada Rumah Sakit untuk memudahkan proses bisnis antara lain rekam medik, data pasien, proses rawat jalan, penyimpanan obat, apotek, dan akuntansi. Sistem informasi manajemen pada rumah sakit biasa disebut dengan SIM RS, yang merupakan himpunan atau kegiatan prosedural yang saling terkait dan terorganisir untuk mencapai tujuan bisnis dengan mengolah dan menyajikan informasi yang efisien, akurat dan sesuai dengan kebutuhan fungsi manajemen dan pengambilan keputusan.

SIM RS harus selalu mengikuti perkembangan kebutuhan dan teknologi baik secara online maupun offline, salah satu contoh rumah sakit yang beradaptasi secara baik adalah Rumah Sakit Umum Daerah (RSUD) Sidoarjo. Sistem telah digunakan sejak tahun 2003 namun masih berbasis desktop hingga tahun 2008 mengalami pergantian pengembang dan berubah berbasis web hingga sekarang. Pada SIM RS RSUD Sidoarjo terdapat beberapa bagian antara lain Billing System, Farmasi, Akutansi, Keuangan, Bank Darah, Aset, Kepegawaian, Pendidikan, Asuhan Keperawatan, Inventory, Rekam Medis Elektronik, Sistem Antrian, Sistem Informasi Rawat, Informasi Kamar, Help Desk, summary Record, Manajemen Operasi, Manejemen HD, Alamat, ETamat, Website, Layanan Pengaduan, Remunerasi, dan E-Office. Pengguna SIM RS di Rumah Sakit Umum Daerah Sidoarjo terdiri dari beberapa bagian, yaitu Tenaga Medis, Tenaga Keperawatan, Tenaga Farmasi, dan Tenaga Non Medis. 
Banyak penelitian yang dilakukan untuk menganalisis penerimaan pengguna pada suatu sistem informasi, antara lain penelitian yang menganalisis keterkaitan antara faktor yang mempengaruhi kualitas [8], penelitian yang menganalisis faktor kemanfaatan dan kemudahan pada sistem OPAC [9], penelitian lain juga banyak yang menganalisis mengenai penerimaan dan penggunaan aplikasi. Penelitian-penelitian tersebut menggunakan metodologi yang sesuai dengan permasalahan dan kebutuhan seperti penggunaan metode UTAUT (Unified Theory of Acceptance and Use of Technology) untuk menganalisis penerimaan dan penggunaan aplikasi dan model TAM (Technology Acceptance Model) untuk menganalisis penerimaan teknologi.

Pada RSUD Sidoarjo tidak pernah dilakukan analisis untuk mengetahui sejauh mana tingkat penerimaan pengguna terhadap teknologi yang digunakan sehingga model yang sesuai untuk tujuan tersebut adalah TAM. TAM dikembangkan oleh Davis tahun 1989 menjelaskan konsep perilaku pemakai dalam menerima dan menggunakan sistem informasi [2], TAM umumnya digunakan untuk menganalisis penerimaan individual terhadap penggunaan sistem informasi [10]. TAM yang dikembangkan dari teori psikologis menjelaskan perilaku penggunaan teknologi informasi yaitu berdasarkan kepercayaan, sikap, keinginan, dan hubungan perilaku pengguna.

Technology Acceptance Model pada awalnya menggunakan lima konstruk utama, yang meliputi perceived usefulness, perceived ease of use, attitude toward using, esternal variables, dan behavioral intention to use [10]. Perceived Usefullness didefinisikan sebagai tingkat kepercayaan pengguna terkait teknologi baru dapat meningkatkan performa pengguna, perceived ese of use didefinisikan sebagai kepercayaan pengguna akan teknologi baru yang bebas dari resiko. Sehingga disimpulkan bahwa TAM menjelaskan persepsi pengguna dalam menentukan sikap terkait pemanfaatan teknologi. SIMRS di RSUD Sidoarjo terdiri dari beberapa modul yang belum pernah dilakukan analisis terkait penerimaan teknologi sehingga perlu dilakukan analisis secara menyeluruh tidak hanya analisis berdasarkan modul yang telah dibangun.

\section{METODOLOGI PENELITIAN}

Metodologi yang digunakan pada penelitian ini meliputi studi literatur, penentuan variabel penelitian, pengumpulan data dan observasi, penentuan hipotesis, pengembangan instrumen, penyebaran kuesioner, pengolahan data dan analisis hasil, kesimpulan.

\subsection{Studi Literatur}

Pada tahap ini dilakukan pengumpulan dan telaah terhadap literatur yang ada terkait penelitian yaitu analisis penerimaan teknologi dan TAM. Studi yang dilakukan meliputi jurnal, prosiding, buku, dan hasil riset atau penelitian, internet, dan sumber lain yang mendukung penelitian. 


\subsection{Penentuan Variabel Penelitian}

Pada tahap ini dilakukan pengelompokkan masalah berdasarkan model yang digunakan, yaitu TAM (Technology Acceptance Model). Hasil dari tahapan ini adalah variabel yang akan digunakan sesuai dengan permasalahan yang ada di RSUD Sidoarjo.

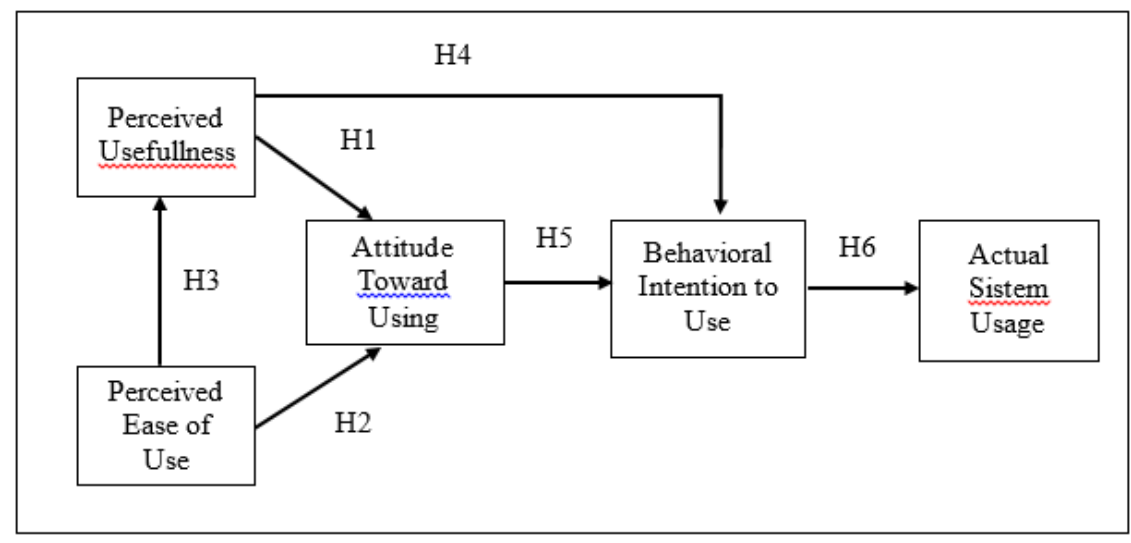

Gambar 1. TAM (Technology Acceptance Model)

Pada gambar 1 ditunjukkan bahwa penggunaan dipengaruhi oleh 6 keterkaitan antar variabel, antara lain pengaruh perceived ease of use terhadap perceive usefullness, pengaruh perceived usefullenss terhadap attitude toward using, pengaruh perceived ease of use terhadap attitude toward using, pengaruh perceived usefullness terhadap behavioral intention to use, pengaruh attitude toward using terhadap behavioral intention to use, dan pengaruh behavioral intention to use terhadap actual sistem usage.

\subsection{Pengumpulan Data dan Observasi}

Observasi dilakukan sebanyak 3 kali dan wawancara dilakukan sebanyak 2 kali pada tahap ini, sehingga diperlukan banyak diskusi terkait permasalahan yang terjadi. Hasil wawancara menunjukkan bahwa tim SIMRS RSUD Sidoarjo sangat membutuhkan analisis ini dikarenakan pihak rumah sakit sangat membutuhkan evaluasi dan rekomendasi perbaikan terhadap modul yang telah diterapkan pada SIMRS. Pihak Rumah Sakit juga membutuhkan pemahaman terkait penerimaan pengguna terhadap SIMRS.

\subsection{Penentuan Hipotesis}

Tujuan penentuan hipotesis adalah untuk menguji tingkat penerimaan SIMRS, sedangkan tujuan observasi adalah mengetahui kesesuaian antara variabel dengan obyek penelitian. Sehingga tahap ini adalah merupakan tahap awal yang penting dalam metodologi penelitian.

\subsection{Pengembangan Instrumen}

Tahapan ini bertujuan untuk mengembangkan variabel yang telah melewati tahap penentuan hipotesis untuk dikembangkan menjadi 
instrumen penelitian yang sesuaikan pada indikator-indikator variabel, kemudian menyusun pada lembar kuesioner untuk masing-masing variabel yang telah ditentukan sebelumnya, kemudian menyusun pertanyaan berdasarkan indikator, kemudian melakukan analisis dan seleksi pertanyaan yang telah ditentukan sebelumnya. Teknik pengolahan dilakukan menggunakan skala likert yang ditunjukkan pada tabel 1 .

Tabel 1. Penentuan Jawaban Kuesioner

\begin{tabular}{ll}
\hline Skor & Kriteria jawaban \\
\hline 1 & Sangat Tidak Setuju (STT) \\
\hline 2 & Tidak Setuju (TS) \\
\hline 3 & Netral (N) \\
\hline 4 & Setuju (S) \\
\hline 5 & Sangat Setuju (SS) \\
\hline
\end{tabular}

Pada tabel 1 ditunjukkan kriteria jawaban berdasarkan skala likert dengan skala 1 sampai dengan 5, dari nilai 1 menunjukkan nilai terendah dan nilai 5 menunjukkan nilai tertinggi. Nilai terendah mengindikasikan responden sangat tidak setuju dan nilai 5 menunjukkan responden sangat setuju terhadap pertanyaan yang diberikan.

\subsection{Penyebaran Kuesioner}

Pada tahap ini dilakukan penyebaran kuesioner untuk 30 responden untuk menguji validitas dan reliabilitas instrumen yang telah dibuat, kemudian dilakukan pengujian menggunakan uji validitas dan uji reliabilitas sehingga dimungkinkan tidak semua instrumen digunakan pada tahap selanjutnya.

\subsection{Pengolahan Data dan Anaisis Hasil}

Berdasarkan tahap sebelumnya maka pada penelitian ini digunakan metode rumus slovin untuk menetukan jumlah responden yang ditunjukkan pada persamaan 1.

$n=\frac{N}{1+N e^{2}}$

Notasi $\mathrm{N}$ menunjukkan jumlah populasi dan e merupakan batas toleransi kesalahan, sedangkan $n$ merupakan jumlah responden.

\section{HASIL DAN PEMBAHASAN}

\subsection{Pengembangan Instrumen Penelitian}

Hasil dari tahapan pengembangan instrumen adalah menyusun pertanyaan berdasarkan indikator dari setiap variabel, sebagai dasar dari pengembangan instrumen digunakan instrumen dari penelitian sebelumnya, secara detil ditunjukkan pada tabel 2. 
Jurnal Sains Komputer \& Informatika (J-SAKTI)

Volume (2) No.2 September 2018, pp. 210-220

ISSN:2548-9771/EISSN:2549-7200

http://tunasbangsa.ac.id/ejurnal/index.php/jsakti

Tabel 2. Pengembangan Instrumen

\begin{tabular}{|c|c|c|}
\hline No & Variabel & Indikator \\
\hline \multirow[t]{6}{*}{1.} & \multirow[t]{6}{*}{ Perceived Ease Of Use (PEU) } & Mudah dipelajari \\
\hline & & Kemudahan untuk digunakan \\
\hline & & Kemudahan untuk dipahami \\
\hline & & Kemudahan untuk diingat \\
\hline & & Ketersediaan petunjuk penggunaan \\
\hline & & Kemudahan untuk mengakses \\
\hline \multirow[t]{4}{*}{2.} & \multirow[t]{4}{*}{ Perceived Ease of Use (PEU) } & Mudah dipelajari \\
\hline & & Mudah digunakan \\
\hline & & Jelas dan mudah dipahami \\
\hline & & Menambah keterampilan para pengguna \\
\hline \multirow[t]{5}{*}{3.} & \multirow[t]{5}{*}{ Perceived Usefullness (PU) } & Memberikan hasil yang akurat \\
\hline & & Menjawab kebutuhan \\
\hline & & Menjadikan pekerjaan lebih mudah \\
\hline & & Meningkatkan produktivitas user \\
\hline & & Penting bagi pekerjaan \\
\hline \multirow[t]{5}{*}{4.} & \multirow[t]{5}{*}{ Perceived Usefullness (PU) } & Pekerjaan lebih mudah \\
\hline & & Bermanfaat \\
\hline & & Meningkatkan produktivitas \\
\hline & & Meningkatkan kinerja pekerjaan \\
\hline & & Mudah digunakan secara keseluruhan \\
\hline \multirow[t]{6}{*}{5.} & \multirow[t]{6}{*}{ Behavioral Intention to Use (BIU) } & Motivasi untuk tetap menggunakan \\
\hline & & Rencana tetap menggunakan dimasa depan \\
\hline & & $\begin{array}{l}\text { Memotivasi pengguna lain untuk } \\
\text { menggunakan }\end{array}$ \\
\hline & & $\begin{array}{l}\text { Motivasi untuk memberi masukan bagi } \\
\text { penggunaan }\end{array}$ \\
\hline & & Rasa suka dalam penggunaan \\
\hline & & $\begin{array}{l}\text { Keinginan untuk menggunakan secara } \\
\text { mandiri }\end{array}$ \\
\hline \multirow[t]{6}{*}{6.} & \multirow[t]{6}{*}{ Actual System Usage (ASU) } & Kejujuran dalam penggunaan \\
\hline & & Kesesuaian dengan prosedur \\
\hline & & Kepuasan Penggunaan \\
\hline & & Kenyamanan dalam penggunaan \\
\hline & & Memahami cara penggunaan \\
\hline & & Menyampaikan keputusan \\
\hline
\end{tabular}

Pada tabel 2 ditunjukkan pengembangan instrumen yang dihasilkan dari penelitian terdahulu yang selanjutnya digunakan sebagai dasar untuk menentukan pertanyaan dalam kuesioner. Usulan kuesioner ditunjukkan pada tabel 3 .

Tabel 3. Pertanyaan Kuesioner

\begin{tabular}{lll}
\hline Variabel & Indikator & Pertanyaan \\
\hline & Mudah untuk dipelajari & $\begin{array}{l}\text { SIMRS mudah untuk saya } \\
\text { pelajari }\end{array}$ \\
\cline { 2 - 2 } $\begin{array}{l}\text { Perceived Easy Of Use } \\
\text { (PEOU) }\end{array}$ & SIMRS mudah digunakan \\
\cline { 2 - 2 } & & SIMRS mudah dioperasikan \\
\cline { 2 - 3 } & $\begin{array}{l}\text { Kemudahan untuk } \\
\text { dipahami }\end{array}$ & SIMRS mudah untuk saya pahami \\
\hline
\end{tabular}

Analisis Sistem Informasi Pada Rumah Sakit Umum (Ainul Fithrotul A'yun)|215 
Jurnal Sains Komputer \& Informatika (J-SAKTI)

Volume (2) No.2 September 2018, pp. 210-220

ISSN:2548-9771/EISSN:2549-7200

http://tunasbangsa.ac.id/ejurnal/index.php/jsakti

\begin{tabular}{|c|c|c|}
\hline & \multirow{2}{*}{ Kemudahan untuk diingat } & $\begin{array}{l}\text { Saya mudah mengingat fitur-fitur } \\
\text { yang ada pada SIMRS }\end{array}$ \\
\hline & & $\begin{array}{l}\text { Penggunaan SIMRS mudah } \\
\text { diingat }\end{array}$ \\
\hline & $\begin{array}{l}\text { Kemudahan untuk } \\
\text { mengakses }\end{array}$ & SIMRS mudah diakses \\
\hline & Jelas & $\begin{array}{l}\text { Fitur SIMRS mudah untuk } \\
\text { digunakan }\end{array}$ \\
\hline & & $\begin{array}{l}\text { Penggunaan SIMRS jelas dan } \\
\text { dapat dimengerti }\end{array}$ \\
\hline & & $\begin{array}{l}\text { Fitur SIMRS mudah untuk } \\
\text { dipahami }\end{array}$ \\
\hline & Fleksibel & SIMRS fleksibel \\
\hline \multirow{8}{*}{$\begin{array}{l}\text { Perceived Usefullness } \\
\text { (PU) }\end{array}$} & Menjawab Kebutuhan & $\begin{array}{l}\text { SIMRS menjawab kebutuhan saya } \\
\text { dalam menyelesaikan pekerjaan }\end{array}$ \\
\hline & Kontrol bagi pekerjaan & $\begin{array}{l}\text { SIMRS memberi 216oftwar untuk } \\
\text { pekerjaan saya }\end{array}$ \\
\hline & $\begin{array}{l}\text { Menjadikan pekerjaan } \\
\text { lebih mudah }\end{array}$ & $\begin{array}{l}\text { SIMRS memberi kemudahan } \\
\text { untuk pekerjaan saya }\end{array}$ \\
\hline & $\begin{array}{l}\text { Penting bagi pekerjaan } \\
\text { saya }\end{array}$ & $\begin{array}{l}\text { SIMRS penting bagi pekerjaan } \\
\text { saya }\end{array}$ \\
\hline & \multirow[t]{2}{*}{ Waktu } & $\begin{array}{l}\text { Menggunakan SIMRS } \\
\text { memungkinkan saya untuk } \\
\text { menyelesaikan pekerjaan saya } \\
\text { lebih cepat }\end{array}$ \\
\hline & & $\begin{array}{l}\text { Saya menghemat waktu jika } \\
\text { menggunakan SIMRS }\end{array}$ \\
\hline & \multirow[t]{2}{*}{ Manfaat } & $\begin{array}{l}\text { SIMRS berguna bagi pekerjaan } \\
\text { saya }\end{array}$ \\
\hline & & $\begin{array}{l}\text { SIMRS dapat meningkatkan } \\
\text { pekerjaan saya }\end{array}$ \\
\hline \multirow{2}{*}{$\begin{array}{l}\text { Attitude Toward Using } \\
\text { (ATU) }\end{array}$} & Ide yang baik & $\begin{array}{l}\text { Menggunakan SIMRS merupakan } \\
\text { ide yang baik bagi pekerjaan saya }\end{array}$ \\
\hline & Menyenangkan & $\begin{array}{l}\text { Menggunakan SIMRS membuat } \\
\text { pekerjaan saya menyenangkan }\end{array}$ \\
\hline \multirow{8}{*}{$\begin{array}{l}\text { Behavioral Intention to } \\
\text { Use (BIU) }\end{array}$} & \multirow{2}{*}{$\begin{array}{l}\text { Motivasi untuk tetap } \\
\text { menggunakan }\end{array}$} & $\begin{array}{l}\text { Saya menggunakan SIMRS karena } \\
\text { mudah }\end{array}$ \\
\hline & & $\begin{array}{l}\text { SIMRS mudah dipelajari dan } \\
\text { digunakan }\end{array}$ \\
\hline & \multirow{3}{*}{$\begin{array}{l}\text { Rencana tetap } \\
\text { menggunakan dimasa } \\
\text { depan }\end{array}$} & $\begin{array}{l}\text { Saya berharap terus } \\
\text { menggunakan SIMRS di masa } \\
\text { yang akan datang }\end{array}$ \\
\hline & & $\begin{array}{l}\text { Saya berencana menggunakan } \\
\text { SIMRS untuk pekerjaan saya } \\
\text { selanjutnya }\end{array}$ \\
\hline & & $\begin{array}{l}\text { SIMRS saya gunakan secara } \\
\text { berkelanjutan }\end{array}$ \\
\hline & $\begin{array}{l}\text { Memotivasi pengguna lain } \\
\text { untuk menggunakan }\end{array}$ & $\begin{array}{l}\text { Saya akan menyarankan } \\
\text { penggunaan SIMRS kepada teman } \\
\text { yang belum menggunakannya }\end{array}$ \\
\hline & $\begin{array}{l}\text { Rasa suka dalam } \\
\text { penggunaan }\end{array}$ & Saya senang menggunakan SIMRS \\
\hline & Keinginan untuk & Saya memilih menggunakan \\
\hline
\end{tabular}

Analisis Sistem Informasi Pada Rumah Sakit Umum (Ainul Fithrotul A'yun)|216 
Jurnal Sains Komputer \& Informatika (J-SAKTI)

Volume (2) No.2 September 2018, pp. 210-220

ISSN:2548-9771/EISSN:2549-7200

http://tunasbangsa.ac.id/ejurnal/index.php/jsakti

\begin{tabular}{lll}
\hline & $\begin{array}{l}\text { menggunakan secara } \\
\text { mandiri }\end{array}$ & $\begin{array}{l}\text { SIMRS dalam menyelesaikan } \\
\text { pekerjaan saya }\end{array}$ \\
\hline & $\begin{array}{l}\text { Kepuasan pengguna } \\
\text { Kenyamanan dalam }\end{array}$ & $\begin{array}{l}\text { Saya merasa puas dengan kinerja } \\
\text { SIMRS }\end{array}$ \\
\cline { 2 - 3 } & $\begin{array}{l}\text { Saya merasa nyaman dalam } \\
\text { menggunakan SIMRS }\end{array}$ \\
\cline { 2 - 3 } $\begin{array}{l}\text { Mctual System Usage } \\
\text { (ASU) }\end{array}$ & $\begin{array}{l}\text { Semahami cara } \\
\text { penggunaan }\end{array}$ & $\begin{array}{l}\text { Saya memahami cara } \\
\text { menggunakan SIMRS }\end{array}$ \\
\cline { 2 - 3 } & Menyampaikan kepuasan & $\begin{array}{l}\text { Saya menyampaikan kepuasan } \\
\text { terhadap SIMRS kepada } \\
217 \text { oftwa teman pengguna SIMRS }\end{array}$ \\
\cline { 2 - 3 } & & $\begin{array}{l}\text { Saya mengakses SIMRS setiap } \\
\text { hari }\end{array}$ \\
\cline { 2 - 3 } & Frekuensi Penggunaan & $\begin{array}{l}\text { Saya mengakses SIMRS minimal } \\
15 \text { menit setiap kali mengunjungi }\end{array}$ \\
& &
\end{tabular}

\subsection{Uji Validitas}

Hasil uji validitas menggunakan analisis korelasi dengan kriteria jika $r$ hitung $>r$ tabel $(0,361)$ maka instrumen dinyatakan berkorelasi signifikan dengan skor total atau dinyatakan valid, namun jika $r$ hitung $<r$ tabel maka item pertanyaan dinyatakan tidak valid. Hasil uji validitas ditunjukkan pada tabel 4 .

Tabel 4. Hasil Uji Validitas

\begin{tabular}{lllll}
\hline Item & r tabel & r hitung & Hasil & Keterangan \\
\hline $\mathbf{1}$ & 0,361 & 0,399 & Valid & Diterima \\
\hline $\mathbf{2}$ & 0,361 & 0,399 & Valid & Diterima \\
\hline $\mathbf{3}$ & 0,361 & 0,629 & Valid & Diterima \\
\hline $\mathbf{4}$ & 0,361 & 0,699 & Valid & Diterima \\
\hline $\mathbf{6}$ & 0,361 & 0,530 & Valid & Diterima \\
\hline $\mathbf{7}$ & 0,361 & 0,579 & Valid & Diterima \\
\hline $\mathbf{8}$ & 0,361 & 0,630 & Valid & Diterima \\
\hline $\mathbf{9}$ & 0,361 & 0,534 & Valid & Diterima \\
\hline $\mathbf{1 0}$ & 0,361 & 0,581 & Valid & Diterima \\
\hline $\mathbf{1 1}$ & 0,361 & 0,571 & Valid & Diterima \\
\hline $\mathbf{1 2}$ & 0,361 & 0,373 & Valid & Diterima \\
\hline $\mathbf{1 3}$ & 0,361 & 0,264 & Tidak Valid & Dihapus \\
\hline $\mathbf{1 4}$ & 0,361 & 0,384 & Valid & Diterima \\
\hline $\mathbf{1 5}$ & 0,361 & 0,391 & Valid & Diterima \\
\hline $\mathbf{1 6}$ & 0,361 & 0,283 & Tidak Valid & Dihapus \\
\hline $\mathbf{1 7}$ & 0,361 & 0,823 & Valid & Diterima \\
\hline $\mathbf{1 8}$ & 0,361 & 0,702 & Valid & Diterima \\
\hline $\mathbf{1 9}$ & 0,361 & 0,405 & Valid & Diterima \\
\hline $\mathbf{2 0}$ & 0,361 & 0,371 & Valid & Diterima \\
\hline $\mathbf{2 1}$ & 0,361 & 0,637 & Valid & Diterima \\
\hline $\mathbf{2 2}$ & 0,361 & 0,575 & Valid & Diterima \\
\hline $\mathbf{2 3}$ & 0,361 & 0,741 & Valid & Diterima \\
\hline $\mathbf{2 5}$ & 0,361 & 0,488 & Valid & Diterima \\
\hline & 0,361 & 0,508 & Valid & Diterima \\
\hline $\mathbf{2 6}$ & 0,361 & 0,597 & Valid & Diterima \\
\hline & 0,361 & 0,676 & Valid & Dihapus, sama no. 25 \\
\hline
\end{tabular}

Analisis Sistem Informasi Pada Rumah Sakit Umum (Ainul Fithrotul A'yun)|217 
Jurnal Sains Komputer \& Informatika (J-SAKTI)

Volume (2) No.2 September 2018, pp. 210-220

ISSN:2548-9771/EISSN:2549-7200

http://tunasbangsa.ac.id/ejurnal/index.php/jsakti

\begin{tabular}{lllll}
\hline $\mathbf{2 7}$ & 0,361 & 0,504 & Valid & Diterima \\
\hline $\mathbf{2 8}$ & 0,361 & 0,453 & Valid & Diterima \\
\hline $\mathbf{2 9}$ & 0,361 & 0,622 & Valid & Diterima \\
\hline $\mathbf{3 0}$ & 0,361 & 0,449 & Valid & Diterima \\
\hline $\mathbf{3 1}$ & 0,361 & 0,382 & Valid & Diterima \\
\hline $\mathbf{3 2}$ & 0,361 & 0,169 & Tidak Valid & Dihapus \\
\hline $\mathbf{3 4}$ & 0,361 & 0,179 & Tidak Valid & Dihapus \\
\hline $\mathbf{3 5}$ & 0,361 & 0,595 & Valid & Diterima \\
\hline Skor Total & 0,361 & 0,587 & Valid & Diterima \\
\hline
\end{tabular}

Berdasarkan hasil uji validitas pada tabel 4 diketahui bahwa dari 35 item pertanyaan yang diuji ditemukan 4 pertanyaan yang tidak valid dan 1 pertanyaan yang berisi sama dengan pertanyaan lain.

\subsection{Uji Realibilitas}

Berdasarkan penyebaran kuesioner maka dilakukan pula uji realibilitas yang bertujuan untuk mengetahui konsistensi jawaban pada pertanyaan kuesioner, stabilitas data atau temuan. Nilai Cronbach's alpha sebesar 0,912 dari 35 item yang menunjukkan bahwa nilai lebih besar dari 0,6 sehingga instrumen dikatakan reliabel.

\subsection{Analisis Hasil dan Pengolahan Data}

SIMRS RSUD Sidoarjo berisi total 21 modul dan masih 15 modul yang telah digunakan, sedangkan 6 modul masih dalam tahap penyelesaian pengembangan. Sampel data yang digunakan menggunakan rumus slovin dengan nilai total adalah 94 orang, berdasarkan jumlah karyawan pada tabel 5 .

Tabel 5. Jumlah karyawan

\begin{tabular}{ll}
\hline Jenis Anggota & Jumlah \\
\hline Tenaga Medis & 142 \\
\hline Tenaga Keperawatan & 889 \\
\hline Tenaga Farmasi & 27 \\
\hline Tenaga Non Medis & 359 \\
\hline Total & $\mathbf{1 4 3 6}$ \\
\hline
\end{tabular}

Pada tabel 5 dihasilkan jumlah sampel 93,6 dengan pembulatan menjadi 94 karyawan. Berdasarkan hal tersebut disebarkan 112 kuesioner dan kembali 94 kuesioner.

\subsection{Uji Normalitas}

Uji normalitas digunakan untuk mengetahui distribusi normal pada sampel karena model regresi yang baik jika sampel berdistribusi normal atau mendekati normal. Jika probabilitas lebih diatas 0,05 maka model regresi adalah normal. Hasil uji normalitas ditunjukkan pada tabel 6. 
Tabel 6. One-Sample Kolmogorov-Smirnov Test

\begin{tabular}{llrrrrr}
\hline & & $\mathbf{X 1}$ & $\mathbf{X 2}$ & $\mathbf{Y 1}$ & $\mathbf{Y 2}$ & Y3 \\
\hline $\mathbf{N}$ & & 94 & 94 & 94 & 94 & 94 \\
\hline $\begin{array}{l}\text { Normal } \\
\text { Parameters }\end{array}$ & Mean & 41.86 & 23.71 & 7.61 & 26.97 & 14.61 \\
\cline { 2 - 7 } $\begin{array}{l}\text { Most Extreme } \\
\text { Differences }\end{array}$ & Std. Deviation & 3.939 & 2.547 & 1.050 & 2.312 & 1.705 \\
\cline { 2 - 7 } & Absolute & .259 & .168 & .258 & .257 & .181 \\
\cline { 2 - 7 } & Positive & .209 & .168 & .258 & .168 & .181 \\
\cline { 2 - 6 } & Negative & -.259 & -.134 & -.231 & -.257 & -.176 \\
\hline Kolmogorov-Smirnov Z & & 2.508 & 1.632 & 2.502 & 2.496 & 1.760 \\
\hline Asymp. Sig. (2-tailed) & & .000 & .010 & .000 & .000 & .004 \\
\hline
\end{tabular}

Pada tabel 6 ditunjukkan nilai uji normalitas pada seluruh variabel, $\mathrm{N}$ merupakan jumlah data, parameter yang digunakan adalah nilai mean dan standar deviasi, ditunjukkan pula nilai absolute, positive dan negative, dan nilai Kolmogorov-Smirnov Z untuk menunjukkan model berdistribusi normal dan pada tabel 6 ditunjukkan seluruh variabel berdistribusi normal.

\subsection{Uji T}

Uji statistik $\mathrm{T}$ digunakan untuk mengetahui pengaruh suatu variabel independen terhadap dependen dan untuk mengetahui pengaruh variabel dependen dengan tingkat signifikansi 0,05 . Hasil uji T ditunjukkan pada tabel 7.

Tabel 7. Hasil Uji T

\begin{tabular}{|c|c|c|c|c|c|c|c|c|c|}
\hline & \multicolumn{5}{|c|}{ Paired Differences } & \multirow[b]{3}{*}{$\mathrm{t}$} & \multirow[b]{3}{*}{$\mathrm{df}$} & \multirow{3}{*}{$\begin{array}{l}\operatorname{Sig}(2- \\
\text { tailed })\end{array}$} \\
\hline & & \multirow[b]{2}{*}{ Mean } & \multirow{2}{*}{$\begin{array}{l}\text { Std. } \\
\text { Devia } \\
\text { tion }\end{array}$} & \multirow{2}{*}{$\begin{array}{l}\text { Std. } \\
\text { Error } \\
\text { Mean }\end{array}$} & \multicolumn{2}{|c|}{$\begin{array}{l}\text { 95\% Confidence } \\
\text { Inerval of the } \\
\text { Difference }\end{array}$} & & & \\
\hline & & & & & Lower & Upper & & & \\
\hline Pair 1 & $\mathrm{X} 2-\mathrm{Y} 1$ & 16.106 & 2.127 & .219 & 15.671 & 16.542 & 73.400 & 93 & .000 \\
\hline Pair 2 & $\mathrm{X} 1-\mathrm{Y} 1$ & 34.255 & 3.733 & .385 & 33.491 & 35.020 & 88.972 & 93 & .000 \\
\hline Pair 3 & $\mathrm{X} 1-\mathrm{X} 2$ & 18.149 & 4.045 & 417 & 17.320 & 18.977 & 43.497 & 93 & .000 \\
\hline Pair 4 & $\mathrm{X} 2-\mathrm{Y} 2$ & -3.255 & 2.185 & .225 & -3.703 & -2.808 & -14.447 & 93 & .000 \\
\hline Pair 5 & Y1-Y2 & -19.362 & 1.866 & .192 & -19.744 & -.18 .980 & -100.618 & 93 & .000 \\
\hline Pair 6 & Y2-Y3 & 12.362 & 2.109 & .218 & 11.930 & 12.794 & 56.825 & 93 & .000 \\
\hline
\end{tabular}

Pada tabel 7 ditunjukkan nilai uji $\mathrm{T}$ berdasarkan pasangan variabel dependen dan independen, variabel $\mathrm{X}$ merupakan variabel independen dan variabel $\mathrm{Y}$ merupakan variabel dependen. Berdasarkan tabel tersebut diketahui bahwa keseluruhan pasangan variabel menunjukkan bahwa tingkat signifikansi dibawah 0,05 dan menunjukkan bahwa variabel independen mempunyai pengaruh signifikan terhadap variabel dependen.

\section{SIMPULAN}

Berdasarkan hasil penelitian diketahui bahwa sistem informasi berpengaruh terhadap kinerja sistem yang ada pada RSUD Sidoarjo, 
penelitian ini membuktikan bahwa variabel dan indikator yang dibangun telah sesuai dan memiliki pengaruh yang signifikan. Secara parsial variabelvariabel saling mempengaruhi sehingga menunjukkan bahwa tingkat penerimaan pengguna terhadap teknologi telah baik, namun perlu dikaji kembali saat 6 modul yang masih dikembangkan telah diselesaikan dan digunakan. Saran yang dapat diberikan dari penulis adalah perlu dilakukan analisis selain dari sisi pengguna misalkan dari sisi pengembang terkait kesesuaian kebutuhan dengan perkembangan teknologi.

\section{DAFTAR PUSTAKA}

[1] Nurjaman, A., \& Hadi, K. Organisasi dan Mnajemen Pemerintahan. Universitas Muhammadiyah: Malang. 2003.

[2] Devi, N. L. N. S., \& Suartana, I. W. Analisis Technology Acceptance Model (TAM) Terhadap Penggunaan Sistem Informasi Di Nusa Dua Beach Hotel \& Spa. E-Jurnal Akuntansi, 167-184. 2014.

[3] Hartono, J. Analisis dan Desain Sistem Informasi: pendekatan terstruktur teori dan praktek aplikasi bisnis. Yogyakarta: Andi. 2005

[4] Suharso, W. (2018). Penerapan Scrum dan Algoritma COCOMO Pada Aplikasi Manajemen Proyek Perangkat Lunak. SATIN-Sains dan Teknologi Informasi, 4(1), 97-104. 2018.

[5] Suharso, W., Widyanto, A. N. S., \& Sari, Z. SISTEM INFORMASI PELAPORAN PADA UPTD PENDIDIKAN. Jurnal INSTEK (Informatika Sains dan Teknologi), 3(1), 101-110. 2018.

[6] Sarita, N., Aria, R. R., \& Susliansyah, S. Perancangan Program Peminjaman Dan Pengembalian Buku Pada Perpustakaan (Studi Kasus Smp Pgri 1 Cibinong). J-SAKTI (Jurnal Sains Komputer dan Informatika), 1(2), 215-222. 2017.

[7] Waluyo, A. Perancangan Website Dinas Pendidikan Pemuda Dan Olah Raga (Studi Kasus Dinas Pendidikan Pemuda Dan Olah Raga Kabupaten Kebumen). J-SAKTI (Jurnal Sains Komputer dan Informatika), 1(2), 186196. 2017.

[8] Fathoni, M. A., Marthasari, G. I., \& Suharso, W. Analisis Pengaruh System Quality, Information Quality, Service Quality Terhadap Net Benefit Pada Sistem KRS-Online UMM. Kinetik, 2(3). 197-206. 2017.

[9] Kharismaya, C., Dewi, L. S., Arisawati, E., \& Handayanna, F. Analisa Kemanfaatan Dan Kemudahan Terhadap Penerimaan Sistem OPAC Menggunakan Metode TAM. J-SAKTI Uurnal Sains Komputer dan Informatika), 1(1), 37-47. 2017.

[10] Wairisal, L. P., \& Khusniyah, N. Analisis Perilaku Penggunaan Teknologi Informasi (Studi pada Dosen Universitas Pattimura Ambon). Jurnal Aplikasi Manajemen, 10(4), 761-771.2012. 